\title{
Effect of water stress on seedling growth in two species with different abundances: the importance of Stress Resistance Syndrome in seasonally dry tropical forest
}

Wanessa Nepomuceno Ferreira ${ }^{1 *}$, Claudivan Feitosa de Lacerda ${ }^{2}$, Rafael Carvalho da Costa ${ }^{3}$ and Sebastião Medeiros Filho ${ }^{4}$

Received: December 10, 2014. Accepted: April 7, 2015

\begin{abstract}
In seasonally dry tropical forests, species carrying attributes of Stress Resistance Syndrome (SRS) may have ecological advantages over species demanding high quantities of resources. In such forests, Poincianella bracteosa is abundant, while Libidibia ferrea has low abundance; therefore, we hypothesized that P. bracteosa has characteristics of low-resource species, while L. ferrea has characteristics of high-resource species. To test this hypothesis, we assessed morphological and physiological traits of seedlings of these species under different water regimes $(100 \%, 70 \%$, $40 \%$, and $10 \%$ field capacity) over 85 days. For most of the studied variables we observed significant decreases with increasing water stress, and these reductions were greater in $L$. ferrea. As expected, $L$. ferrea maximized their growth with increased water supply, while P. bracteosa maintained slower growth and had minor adjustments in biomass allocation, characteristics representative of low-resource species that are less sensitive to stress. We observed that specific leaf area, biomass allocation to roots, and root/shoot ratio were higher in L. ferrea, while biomass allocation to leaves and photosynthesis were higher in P. bracteosa. Results suggest that the attributes of SRS can facilitate high abundance of $P$. bracteosa in dry forest.
\end{abstract}

Keywords: abundance, high-resource species, Libidibia ferrea, low-resource species, morphological traits, physiological traits, Poincianella bracteosa, Stress Resistance Syndrome, water stress

\section{Introduction}

The distribution and abundance of plant species are determined, in large part, during initial regeneration stages, when seedlings and young plants are more vulnerable to environmental conditions and incur on higher mortality rates associated with various biotic and abiotic factors (Harper 1977; Kitajima \& Fenner 2000). Such factors may act as stressors, exerting deleterious effects on plant growth and development (Larcher 2006; Kranner et al. 2010; Taiz \& Zeiger 2013).

Stress is characterized as a significant deviation from the optimal conditions for life, which induces changes and responses in all functional levels of the organism (Larcher 2006; Kranner et al. 2010). Drought (Figueirôa et al. 2004; Sausen \& Rosa 2010), salinity (Ahmad et al. 2010), extreme temperatures (Keles \& Öncel 2002), oxygen deficiency (Mustroph \& Albrecht 2003), and heavy metals excess in soil (Roychoudhury et al. 2012) are some of the major abiotic or environmental sources of stress that restrict plant metabolism and growth. When these factors exceed optimum tolerance levels, the effects of stress can be manifested in plant development, structure, physiological, and biochemical processes.

Among abiotic factors, drought is considered the main obstacle to plant establishment (Moles \& Westoby 2004), especially in seasonally dry tropical forests (SDTFs). The SDTF of northeastern Brazil (caatinga) occurs under a prevailing semiarid climate with high evapotranspiration potential (1500-2000 $\left.\mathrm{mm} \mathrm{year}^{-1}\right)$ and low precipitation (300-1000 mm year $\left.{ }^{-1}\right)$ that is usually concentrated within 3-5 months (Sampaio 1995). Rainfall patterns during the wet season are also characterized by heavy rainfall events (exceeding $100 \mathrm{~mm}$ ) in a single day and irregular seasonality (i.e., the rainy season may start and end at different months between years) (Sampaio 2010). Thus, the inconstancy of

\footnotetext{
${ }^{1}$ Programa de pós-graduação em Ecologia e Recursos Naturais, Centro de Ciências, Universidade Federal do Ceará, 60020-181, Fortaleza, CE, Brazil

${ }^{2}$ Departamento de Engenharia Agrícola, Centro de Ciências Agrárias, Universidade Federal do Ceará, 60020-181, Fortaleza, CE, Brazil

${ }^{3}$ Departamento de Biologia, Centro de Ciências, Universidade Federal do Ceará, 60020-181, Fortaleza, CE, Brazil

${ }^{4}$ Departamento de Fitotecnia, Centro de Ciências Agrárias, Universidade Federal do Ceará, 60020-181, Fortaleza, CE, Brazil

"Corresponding author: wanessanepomuceno@hotmail.com
} 
the first rains and the occurrence of dry spells during the rainy season are significant causes of mortality of seeds and seedlings by desiccation (McLaren \& McDonald 2003; Vieira \& Scariot 2006).

The effects of drought are highly variable depending on length, speed of stress imposition, and stage of plant development, and plants respond to stress through a complex net of physiological and morphological changes (Pimentel 2004). During evolution, many tree species have developed various mechanisms to enhance drought adaptation, including well-developed root systems, growth rate adjustment, plant structure modifications, and increased water use efficiency (Yin et al. 2005).

According to the stress resistance syndrome (SRS), species adapted to low-resource environments (water, nutrient, or light limitations) present a set of attributes, such as low rates of photosynthesis, low nutrient uptake, low tissue turnover, high leaf longevity, high root/shoot ratio, high ability to accumulate reserves, production of small and thick leaves, and high investments in secondary defense compounds (Chapin III 1980; Coley et al. 1985; Chapin III et al. 1993; Aerts \& Chapin III 2000). Species adapted to low-resource environments tend to respond little relatively to variations in resource availability, showing low phenotypic plasticity (Chapin III et al. 1993). These species grow slowly even when they have ideal resource supplies because they divert resources to other functions besides growth, especially storage or defense. Thus, such species tend to conserve resources under unfavorable conditions, which increase survival at the expense of vegetative growth (Chapin III 1980; Lambers \& Poorter 1992; Aerts \& Peijl 1993; Chapin III et al. 1993; Valladares et al. 2000; Pearson et al. 2003). In contrast, plants adapted to high-resource environments have characteristics such as high rates of photosynthesis, high nutrient uptake, high tissue turnover, low leaf longevity, and low root/shoot ratio. These species are typically more plastic, modifying allocation patterns to increase resource acquisition (Chapin III 1980; Chapin III et al. 1993).

Species that occur in SDTFs and possess SRS attributes may have ecological advantages (growth and survival) under water stress conditions, allowing them to maintain higher abundances than species that do not possess these attributes (high resource-species). Phytosociological studies in caatinga show that Poincianella bracteosa is a species with a high abundance of individuals where water resources are limited (Mendes 2003; Moreira et al. 2007; Lima 2011; Costa \& Araújo 2012), while Libidibia ferrea has low abundances in these areas and preferentially occurs on the banks of temporary rivers (Queiroz 2009). Such abundance differences between species may be related to different strategies to cope with drought. Thus, we hypothesized that $P$. bracteosa has characteristics of a low-resource species, allowing it to be less affected by water stress than L. ferrea, which we characterized as a high-resource species. To test this hypothesis, we assessed morphological and physiological traits during the initial growth of seedling of these species in different water regimes. If resource use strategies are indeed related to stress tolerance, we expect to find low-resource species showing little variation in morphological and physiological traits, while high-resource species should respond positively to increased water availability.

\section{Material and methods}

\section{Site and studied species}

The experiment was conducted from September to December 2013 in a greenhouse located at the Meteorological Station of the Federal University of Ceara, in the city of Fortaleza $\left(3^{\circ} 43^{\prime} 02^{\prime \prime} \mathrm{S}-38^{\circ} 32^{\prime} 35^{\prime \prime} \mathrm{W}\right)$.

Both the studied species belong to the family Fabaceae, subfamily Caesalpinioideae. Poincianella bracteosa (Tul.) L.P. Queiroz is a deciduous tree found mainly in dry formations such as caatinga, cerrado, seasonal forests, and coastal dunes (Queiroz 2009). Libidibia ferrea (Mart. ex Tul.) L.P. Queiroz is a semi-deciduous tree that prefers loamy soils and is found primarily in the margins of temporary rivers and less frequently in caatinga (Maia 2004; Queiroz 2009).

The fruits of the species were collected from July to September 2013 in mature individuals, located in an area of caatinga at Fazenda Experimental Vale do Curu, Pentecoste, Brazil $\left(3^{\circ} 47^{\prime} 34^{\prime \prime} \mathrm{S}-39^{\circ} 16^{\prime} 13^{\prime \prime} \mathrm{W}\right)$. The seeds were removed and stored in a chamber with controlled temperature $\left(10^{\circ} \mathrm{C}\right.$ and $60 \%$ relative humidity) until the beginning of the experiment. Fertile branches were collected for accurate species identification. L. ferrea and P. bracteosa were incorporated into the collections of the Herbarium Prisco Bezerra of Federal University of Ceara with vouchers 54707 and 54708, respectively.

\section{Experimental design}

The experimental design was a randomized block with four replicates, arranged in subplots. The plots were formed by the two species (P. bracteosa and L. ferrea) and the subplots by four irrigation regimes $(100 \%, 70 \%, 40 \%$, and $10 \%$ field capacity). Each subplot was represented by three pots with one plant per pot. Therefore, 96 plants were used in total ( 4 blocks $\mathrm{x} 2$ species $\mathrm{x} 4$ treatments $\mathrm{x} 3$ plants per treatment).

On September 21, seeds of L. ferrea and P. bracteosa were sown in trays $(128$ cells) containing a mixture of sand and compost (2:1). L. ferrea seeds were scarified with sandpaper to overcome physical dormancy. Ten days after sowing (01-October), emerging seedlings had two fully expanded leaves and were transplanted into pots with $7 \mathrm{~L}$ capacity $(32.5 \mathrm{~cm}$ high $\times 16 \mathrm{~cm}$ wide on top $\times 11 \mathrm{~cm}$ wide in the base), and filled with $8 \mathrm{~kg}$ of dry soil, collected from the same caatinga area where the seeds were collected. 
The soil was collected at $30 \mathrm{~cm}$ depth, and showed a sandy loam texture and the following properties: $\mathrm{pH}=6.1, \mathrm{P}=5$ $\mathrm{mg} \mathrm{kg}{ }^{-1}$, and $\mathrm{Ca}^{2+}, \mathrm{Mg}^{2+}, \mathrm{Na}^{+}$, and $\mathrm{K}^{+}$of $3.2,1.2,0.17$, and $0.42 \mathrm{cmol}_{\mathrm{c}} \mathrm{kg}^{-1}$, respectively.

After transplanting, all pots were irrigated at field capacity (FC) during five days for acclimatization, and then subjected to four irrigation levels: $100 \%, 70 \%, 40 \%$, and $10 \%$ $\mathrm{FC}$, hereafter referred to as $\mathrm{T}_{100}, \mathrm{~T}_{70}, \mathrm{~T}_{40}$, and $\mathrm{T}_{10}$, respectively. The field capacity of soil was previously determined using the direct gravimetric method (Souza et al. 2000). The maximum water retention capacity in $8 \mathrm{~kg}$ of soil was 1.3 $\mathrm{L}$; thus, the $\mathrm{T}_{100}$ treatment pots had a weight of $9.3 \mathrm{~kg}$. The other treatments showed the following amounts of water and weight: $\mathrm{T}_{70}=0.91 \mathrm{~L} ; 8.91 \mathrm{~kg}, \mathrm{~T}_{40}=0.52 \mathrm{~L} ; 8.52 \mathrm{~kg}$, and $\mathrm{T}_{10}=0.13 \mathrm{~L} ; 8.13 \mathrm{~kg}$.

Water levels were monitored every $48 \mathrm{~h}$, by weighing the pots on a balance with $5 \mathrm{~g}$ accuracy and the amount of water evapotranspired was reset based on the difference between the actual weight of the pot and the prefixed weight for each treatment, assuming the water had a weight:volume ratio of 1:1. Throughout the experimental period, the temperature data and relative humidity $(\mathrm{RH})$ were recorded every 10 minutes by a data-logger $\left(\mathrm{HOBO}^{\circ}\right.$, Onset) installed inside the greenhouse. Mean minimum and maximum temperatures measured were 25 and $36^{\circ} \mathrm{C}$, and the mean minimum and maximum $\mathrm{RH}$ were $41 \%$ and $82 \%$, respectively.

\section{Morphological measurements}

Measurements of ecophysiological traits were taken at 85 days after treatment initiation, corresponding to 100 days after sowing. The seedling height was measured between the soil surface and insertion of the last leaf, and the stem diameter was measured at ground level. All fully expanded leaves were counted.

The total leaf area $(L A)$ was assessed using a leaf area meter (LI-COR', model LI-3100C). Roots were washed and the clods of soil attached to the roots were broken carefully to avoid root loss. All plant material was placed separately in an oven at $80^{\circ} \mathrm{C}$ for $48 \mathrm{~h}$ and then weighed on a precision balance to $0.01 \mathrm{~g}$.

The total dry mass (TDM) was calculated as the sum of the dry mass of leaves $\left(D M_{L}\right)$, stems $\left(D M_{S}\right)$, and roots $\left(D M_{R}\right)$. The biomass allocation in each part of the plant was calculated as the percentage of leaves $\left(B A_{L}\right)$, stems $\left(B A_{S}\right)$, and roots $\left(B A_{R}\right)$ in relation to TDM. The root/shoot ratio was $(R / S)=D M_{R} /\left(D M_{L}+D M_{S}\right)$ and the specific leaf area $(S L A)=L A / D M_{L}($ Cornelissen et al. 2003).

The relative growth rate $(R G R)$ was calculated as: $\left(\ln M_{2}-\ln M_{1}\right) /\left(t_{2}-t_{1}\right)$, where $M_{1}$ and $M_{2}$ represent final and initial mass total; $t_{1}$ and $t_{2}$ to the end and start time. For each species, "proportional growth" was calculated as the ratio of the average TDM obtained in each treatment with water restriction $\left(\mathrm{T}_{10}, \mathrm{~T}_{40}, \mathrm{~T}_{70}\right)$ over the control $\left(\mathrm{T}_{100}\right)$. This calculation was based on Munns (2002) who reported that stress tolerance could be assessed as the proportion of biomass production under stress conditions compared to that produced under control conditions.

\section{Physiological measurements}

Measurements of stomatal conductance $(g s)$, transpiration $(E)$, and photosynthesis $(A)$ were carried out using an infrared gas analyzer (IRGA ADC system, Hoddesdon, UK) coupled to a source of artificial light with an intensity of approximately $1300 \mu \mathrm{mol} \mathrm{m}^{-2} \mathrm{~s}^{-1}$. The evaluations were performed between 09:00 and 12:00 am, in the third fully expanded leaf pair from the apex to base, and water-use efficiency (WUE) was obtained by the $\mathrm{A} / \mathrm{E}$ ratio (Larcher 2006).

\section{Data analysis}

Data were analyzed using a two-way ANOVA (species and water status were considered as factors), addressing the effects of the interaction, as well as differences between species and for each species between water status treatments. The means were compared by Tukey test at $5 \%$ probability (Banzatto \& Kronka 2006), using the Assistat software (beta version 7.7). Data that did not meet the assumption of normality were transformed to $\ln (x+1)$, but the original data is presented in all graphs.

\section{Results}

\section{Morphological measurements}

The interaction between species and irrigation levels was statistically significant in the following morphological measurements: height, diameter, number of leaves, $L A$, $T D M, R G R$, and $B A_{S}$ (Tab. 1).

In both species, the height of the seedlings increased significantly with water supply (Fig. 1A). In relation to $\mathrm{T}_{10}$, the height of $P$. bracteosa seedlings significantly increased in all treatments by 52,72 , and $80 \%$ in $\mathrm{T}_{40}, \mathrm{~T}_{70}$ and $\mathrm{T}_{100}$, respectively. In $L$. ferrea, the height increased by 76,86 , and $87 \%$ in $\mathrm{T}_{40}, \mathrm{~T}_{70}$ and $\mathrm{T}_{100}$, but $\mathrm{T}_{100}$ and $\mathrm{T}_{70}$ did not differ from each other. The fact that the percentages were higher in $L$. ferrea shows that this species is capable of maximizing growth with increased resources, while $P$. bracteosa maintained slower growth rates.

Stem diameter also increased proportionally to the supply of water for both species (Fig. 1B). In relation to $\mathrm{T}_{10}$, the diameter of $P$. bracteosa seedlings significantly increased in each treatment by 51,62 , and $73 \%$ in $\mathrm{T}_{40}, \mathrm{~T}_{70}$, and $\mathrm{T}_{100}$, respectively. In $L$. ferrea, the stem diameter increased by 56,72 and $74 \%$ in $\mathrm{T}_{40}, \mathrm{~T}_{70}$ and $\mathrm{T}_{100}$, respectively, and similar to the results in height, there were no significant differences between $\mathrm{T}_{70}$ and $\mathrm{T}_{100}$. Interspecific differences only occurred in $\mathrm{T}_{40}$ and $\mathrm{T}_{70}$, with $P$. bracteosa maintaining the lowest averages. 
Table 1. Mean square of growth and gas exchange variables in seedlings of L. ferrea and P. bracteosa subjected to four irrigation regimes (10\%, $40 \%, 70 \%$, and $100 \%$ of field capacity) for 85 days.

* Significant at $5 \%,{ }^{* *}$ Significant at $1 \%$, NS not significant. Degree of freedom (df), leaf area $(L A)$, specific leaf area (SLA), total dry matter (TDM), relative growth rate $(R G R)$, biomass allocation to leaves $\left(B A_{L}\right)$, stem $\left(B A_{S}\right)$ and roots $\left(B A_{R}\right)$, root/shoot ratio $(R / S)$, stomatal conductance $(g s)$, transpiration $(E)$, photosynthesis $(A)$, and water-use efficiency (WUE).

\begin{tabular}{|c|c|c|c|c|c|c|}
\hline \multirow{2}{*}{ Variables } & \multicolumn{6}{|c|}{ Sources of variation } \\
\hline & Block & Species (A) & Residual-a & Irrigation levels (B) & Interaction $(\mathrm{A}) \mathrm{x}(\mathrm{B})$ & Residual-b \\
\hline Height & $0.00191^{\mathrm{NS}}$ & $5.59637^{\star *}$ & 0.00195 & $4.79896^{\star *}$ & $0.20373^{\star *}$ & 0.01231 \\
\hline Diameter & $0.00120^{\mathrm{NS}}$ & $0.02099^{*}$ & 0.00159 & $1.64418^{* *}$ & $0.00691^{*}$ & 0.00192 \\
\hline $\mathrm{N}^{\circ}$ leaves & $0.00195^{\mathrm{NS}}$ & $2.49247^{\star \star}$ & 0.00243 & $1.76481^{\star \star}$ & $0.04828^{*}$ & 0.01475 \\
\hline$L A$ & $0.00635^{\mathrm{NS}}$ & $0.88038^{* *}$ & 0.01926 & $13.02854^{* *}$ & $0.05035^{*}$ & 0.01531 \\
\hline SLA & $103.953^{\mathrm{NS}}$ & $25646.89^{* *}$ & 225.354 & $1540.8912^{* *}$ & $294.6748^{\mathrm{NS}}$ & 136.3905 \\
\hline$T D M$ & $0.00351^{\mathrm{NS}}$ & $1.08693^{* *}$ & 0.00460 & $10.74152^{* *}$ & $0.09041^{* *}$ & 0.00814 \\
\hline$R G R$ & $0.00001^{\mathrm{NS}}$ & $0.00007^{\mathrm{NS}}$ & 0.00003 & $0.00284^{\star *}$ & $0.00007^{\star *}$ & 0.00001 \\
\hline$B A_{L}$ & $6.52419^{\mathrm{NS}}$ & $1605.92537^{* *}$ & 6.97773 & $36.74079^{*}$ & $23.03355^{\mathrm{NS}}$ & 9.40258 \\
\hline$B A_{s}$ & $4.33577^{\star}$ & $373.93290^{* *}$ & 0.37134 & $183.65043^{* *}$ & $73.25856^{* *}$ & 5.41020 \\
\hline$B A_{R}$ & $18.76650^{\mathrm{NS}}$ & $430.00846^{\star *}$ & 8.60188 & $60.19875^{\mathrm{NS}}$ & $15.42913^{\mathrm{NS}}$ & 18.83149 \\
\hline$R / S$ ratio & $0.03477^{\mathrm{NS}}$ & $0.63092^{*}$ & 0.02628 & $0.10613^{\mathrm{NS}}$ & $0.03886^{\mathrm{NS}}$ & 0.03018 \\
\hline$g s$ & $0.00283^{\mathrm{NS}}$ & $0.00001^{\mathrm{NS}}$ & 0.00617 & $0.14429^{* *}$ & $0.00066^{\mathrm{NS}}$ & 0.00218 \\
\hline E & $0.96494^{\mathrm{NS}}$ & $0.25294^{\mathrm{NS}}$ & 0.35666 & $42.42474^{* *}$ & $0.22579^{\mathrm{NS}}$ & 0.32792 \\
\hline$A$ & $5.23057^{\mathrm{NS}}$ & $13.76157 *$ & 0.63175 & $299.28667 * *$ & $4.55035^{\mathrm{NS}}$ & 2.55521 \\
\hline WUE & $0.35494^{\mathrm{NS}}$ & $0.36583^{\mathrm{NS}}$ & 0.11309 & $0.23896^{*}$ & $0.01514^{\mathrm{NS}}$ & 0.05181 \\
\hline $\mathrm{df}$ & 3 & 1 & 3 & 3 & 3 & 18 \\
\hline
\end{tabular}

In relation to $\mathrm{T}_{10}$, the number of leaves of $P$. bracteosa seedlings increased by 50,60 , and $69 \%$ in $\mathrm{T}_{40}, \mathrm{~T}_{70}$, and $\mathrm{T}_{100}$ respectively, but there was no significant difference between $\mathrm{T}_{40}$ and $\mathrm{T}_{70}$, as well as between $\mathrm{T}_{70}$ and $\mathrm{T}_{100}$ (Fig. 1C). L. ferrea increased the number of leaves by 67,71 , and $73 \%$ in $\mathrm{T}_{40}, \mathrm{~T}_{70}$ and $\mathrm{T}_{100}$ respectively, and these three treatments were not significantly different from each other, but they did differ from $\mathrm{T}_{10}$ (Fig. 1C). Comparing the two species, we observed that in all treatments the number of leaves was significantly lower in P. bracteosa. The $\mathrm{T}_{10}$ treatment also induced senescence and abscission of leaflets in L. ferrea, from day 55 until the end of the experiment. This phenomenon was not recorded in P. bracteos $a$, which continued producing leaflets until the end of the experiment.

The $L A$ followed a similar pattern observed in the number of leaves, which increased because of the increased supply of water (Fig. 1D). In relation to $\mathrm{T}_{10}$, the $L A$ of P. bracteosa seedlings increased by 81,92 , and $94 \%$ in $\mathrm{T}_{40}$, $\mathrm{T}_{70}$, and $\mathrm{T}_{100}$, respectively, with significant differences among all treatments. In $L$. ferrea, $L A$ increased by 85,93 , and $94 \%$ in $\mathrm{T}_{40}, \mathrm{~T}_{70}$, and $\mathrm{T}_{100}$, respectively, but there were no significant differences between $\mathrm{T}_{70}$ and $\mathrm{T}_{100}$. Interspecific differences occurred in the $\mathrm{T}_{10}, \mathrm{~T}_{40}$, and $\mathrm{T}_{70}$ treatments, in which P. bracteosa maintained the lowest values in relation $L$. ferrea.

In the $S L A$, there was no significant interaction among species and irrigation levels (Tab. 1). However, there were species differences, with $P$. bracteosa having lower overall average SLA than L. ferrea (Tab. 2).
The TDM increased with increased water availability, and significant differences among all treatments were observed for both species (Fig. 1E). In relation to $\mathrm{T}_{10}, T D M$ increased by 82,94 , and $96 \%$ for $P$. bracteosa seedlings and 88,95 , and $96 \%$ for $L$. ferrea seedlings in $\mathrm{T}_{40}, \mathrm{~T}_{70}$, and $\mathrm{T}_{100}$ respectively. Interspecific differences were also found in all treatments except $\mathrm{T}_{10}$, with $P$. bracteosa maintaining the lowest averages.

In both species, $R G R$ showed significant differences between all treatments, except between $\mathrm{T}_{70}$ and $\mathrm{T}_{100}$ (Fig. 1F). In relation to $\mathrm{T}_{10}$, the $R G R$ increased by 63,77 , and $76 \%$ for $P$. bracteosa seedlings and 79,82 , and $84 \%$ for $L$. ferrea seedlings in $\mathrm{T}_{40}, \mathrm{~T}_{70}$, and $\mathrm{T}_{100}$ respectively. Interspecific differences were only found in the $\mathrm{T}_{40}$ treatment, in which $P$. bracteosa obtained a lower average than $L$. ferrea.

The values of the "proportional growth" of TDM obtained in each treatment of water restriction in relation to $\mathrm{T}_{100}$ were: $\mathrm{T}_{10} / \mathrm{T}_{100}=0.039, \mathrm{~T}_{40} / \mathrm{T}_{100}=0.34$, and $\mathrm{T}_{70} / \mathrm{T}_{100}=0.80$ for L.ferrea and $\mathrm{T}_{10} / \mathrm{T}_{100}=0.044, \mathrm{~T}_{40} / \mathrm{T}_{100}=0.24$, and $\mathrm{T}_{70} / \mathrm{T}_{100}$ $=0.70$ for P. bracteosa.

Considering all the treatments, the biomass allocation of L. ferrea seedlings ranged from $22-30 \%$ in leaves, $15-31 \%$ in stems, and $47-55 \%$ in roots, while $P$. bracteosa seedlings had less variation: $38-40 \%$ in leaves, $15-21 \%$ in stems, and $42-45 \%$ in roots. Thus, biomass allocation patterns showed that $P$. bracteosa seedlings are less responsive to changes in water availability, whereas $L$. ferrea seedlings make more observable adjustments (Fig. 2). 

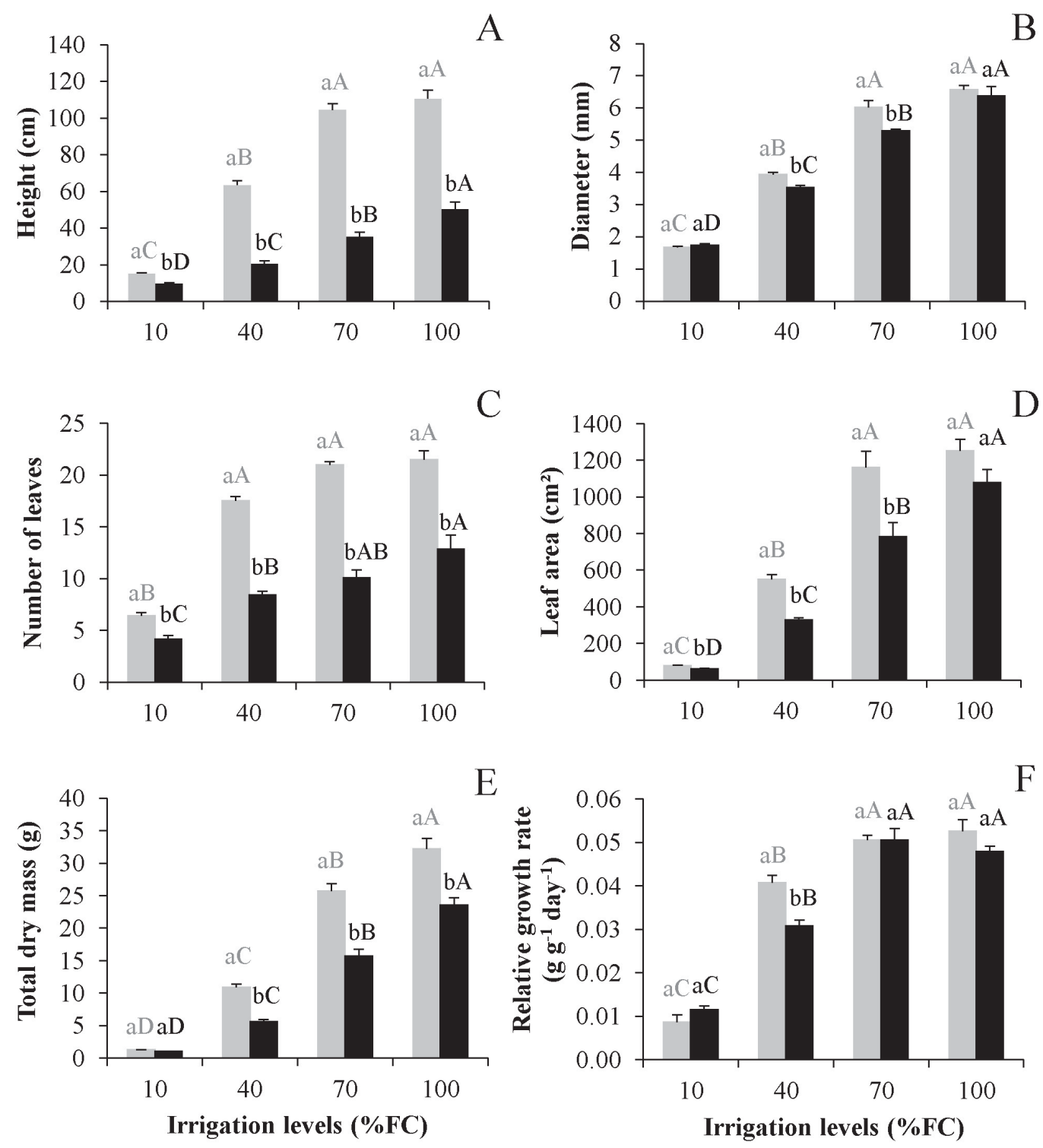

Libidibia ferrea

Poincianella bracteosa

Figure 1. Height (A), diameter (B), number of leaves (C), leaf area (D), total dry mass (E), and relative growth rate (F) of seedlings of $L$. ferrea and $P$. bracteosa that, at 15 days after sowing, were subjected to four irrigation regimes (10\%, $40 \%, 70 \%$, and $100 \%$ of field capacity) for 85 days. Lowercase letters (compare species in the same treatment) and uppercase (compare treatments in the same species) equal, do not differ by Tukey test at $5 \%$ probability. Vertical bars indicate standard error of the mean.

The $R / S$ ratio showed significant differences only between species, in which $L$. ferrea was higher than $P$. bracteosa. Thus, $L$. ferrea showed higher plasticity in the $R / S$ ratio, which varied 3 -fold more $\left(\mathrm{T}_{10}: 1.2\right.$ to $\left.\mathrm{T}_{100}: 0.91\right)$ than P. bracteosa seedlings $\left(\mathrm{T}_{10}: 0.84\right.$ to $\left.\mathrm{T}_{100}: 0.73\right)$.

\section{Physiological measurements}

In all variables of gas exchange ( $g s, E, A$, and $W U E$ ), there was also no significant interaction between species and irrigation levels ( $\operatorname{Tab} 1$ ). The variables $g s, E$, and $A$ were strongly limited by water restriction, with significant differences between all treatments, except between $\mathrm{T}_{70}$ and $\mathrm{T}_{100}$. There were interspecific differences only for photosynthesis, in which $P$. bracteosa showed a higher photosynthetic capacity in relation to L. ferrea (Tab. 2).

Although the species did not differ significantly in the WUE, we observed that $P$. bracteosa has a tendency to be more efficient than L. ferrea. As for the differences between treatments, $\mathrm{T}_{40}$ had the highest average, but did not differ from $\mathrm{T}_{10}$ and $\mathrm{T}_{70}$. The lowest average was in $\mathrm{T}_{100}$, which also was not different from $\mathrm{T}_{10}$ and $\mathrm{T}_{70}$ (Tab. 2). 


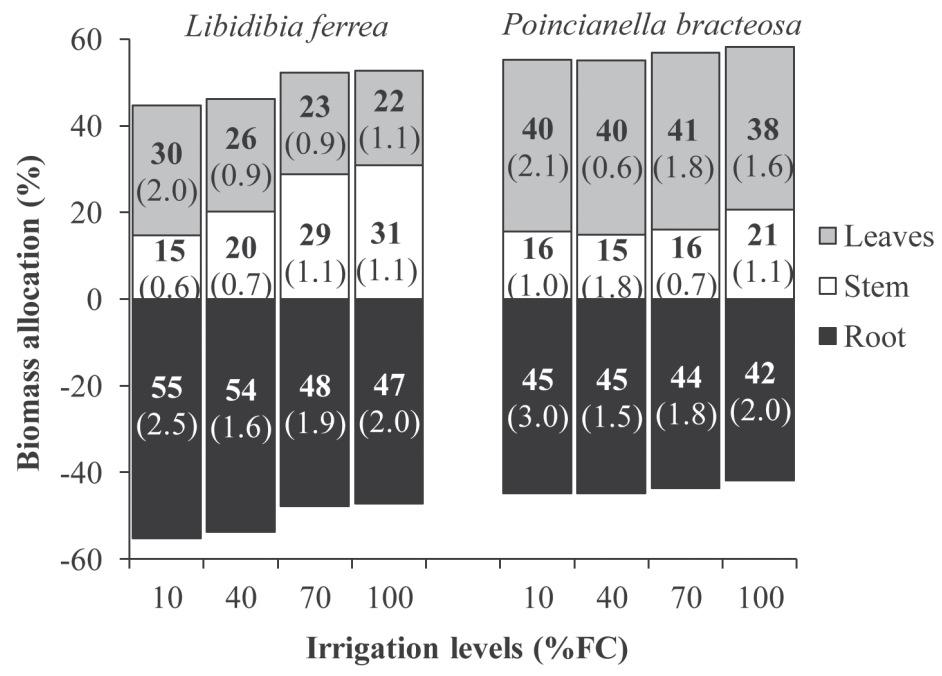

Figure 2. Biomass allocation to roots, stems, and leaves of seedlings of $L$. ferrea and $P$. bracteosa that, at 15 days after sowing, were subjected to four irrigation regimes $(10 \%, 40 \%, 70 \%$, and $100 \%$ of field capacity) for 85 days. Numbers within parentheses indicate standard error of the mean.

Table 2. Average values of growth and gas exchange traits in seedlings of $L$. ferrea and $P$. bracteosa subjected to four irrigation regimes $(10 \%, 40 \%, 70 \%$, and $100 \%$ of field capacity) for 85 days. There were no significant interactions between species and irrigation levels for any of the variables measured. Averages with equal lowercase (species) and uppercase (treatments) letters, do not differ by Tukey test at $5 \%$ probability. Specific leaf area (SLA), biomass allocation to leaves $\left(B A_{L}\right)$ and roots $\left(B A_{R}\right)$, root/shoot ratio $(R / S)$, stomatal conductance $(g s)$, transpiration $(E)$, photosynthesis $(A)$, and water-use efficiency $(W U E)$.

\begin{tabular}{|c|c|c|c|c|c|c|c|c|}
\hline & $\begin{array}{c}S L A \\
\left(\mathrm{~cm}^{2} / \mathrm{g}\right)\end{array}$ & $B A_{L}$ & $B A_{R}$ & $\begin{array}{l}R / S \\
\text { ratio }\end{array}$ & $\begin{array}{c}g s \\
\left(\mathrm{~mol} \mathrm{~m}^{-2} \mathrm{~s}^{-1}\right)\end{array}$ & $\begin{array}{c}E \\
\left(\mathrm{mmol} \mathrm{m}^{-2} \mathrm{~s}^{-1}\right) \\
\end{array}$ & $\begin{array}{c}A \\
\left(\mathrm{mmol} \mathrm{m}^{-2} \mathrm{~s}^{-1}\right)\end{array}$ & WUE \\
\hline \multicolumn{9}{|l|}{ Species } \\
\hline L. ferrea & $194.071 \mathrm{a}$ & $25.342 \mathrm{~b}$ & $50.988 \mathrm{a}$ & $1.076 \mathrm{a}$ & $0.184 \mathrm{a}$ & $3.578 \mathrm{a}$ & $9.277 \mathrm{~b}$ & $2.624 \mathrm{a}$ \\
\hline P. bracteosa & $137.451 \mathrm{~b}$ & 39.511 a & $43.656 \mathrm{~b}$ & $0.795 \mathrm{~b}$ & $0.183 \mathrm{a}$ & $3.756 \mathrm{a}$ & 10.588 a & $2.838 \mathrm{a}$ \\
\hline \multicolumn{9}{|c|}{ Irrigation levels } \\
\hline T10 & $180.787 \mathrm{~A}$ & $34.789 \mathrm{~A}$ & $50.019 \mathrm{~A}$ & $1.059 \mathrm{~A}$ & $0.009 \mathrm{C}$ & $0.447 \mathrm{C}$ & $1.133 \mathrm{C}$ & $2.683 \mathrm{AB}$ \\
\hline $\mathrm{T} 40$ & $173.468 \mathrm{AB}$ & $33.175 \mathrm{AB}$ & $49.299 \mathrm{~A}$ & $1.006 \mathrm{~A}$ & $0.148 \mathrm{~B}$ & $3.593 \mathrm{~B}$ & $10.423 \mathrm{~B}$ & $2.921 \mathrm{~A}$ \\
\hline T70 & $158.534 \mathrm{BC}$ & $32.058 \mathrm{AB}$ & $45.460 \mathrm{~A}$ & $0.855 \mathrm{~A}$ & $0.268 \mathrm{~A}$ & $5.081 \mathrm{~A}$ & $14.218 \mathrm{~A}$ & $2.804 \mathrm{AB}$ \\
\hline T100 & $150.255 \mathrm{C}$ & $29.689 \mathrm{~B}$ & $44.508 \mathrm{~A}$ & $0.822 \mathrm{~A}$ & $0.308 \mathrm{~A}$ & $5.548 \mathrm{~A}$ & $13.956 \mathrm{~A}$ & $2.517 \mathrm{~B}$ \\
\hline
\end{tabular}

\section{Discussion}

In general, the stress imposed by water supply limitation affected the morphological and physiological traits of both species, as it was found significant reductions in height, diameter, number of leaves, leaf area, total dry mass, and restrictions in gas exchange. Several studies with other arid and semiarid species reported similar effects caused by water stress (Silva et al. 2003; Cabral et al. 2004; Figueirôa et al. 2004; Gindaba et al. 2004; Yin et al. 2005; Lenhard et al. 2010).

Although it was not demonstrated in all studied variables, we confirmed that even with increased water supply, $P$. bracteosa presented a slower growth strategy, resembling a low-resource species, while L. ferrea maximized their growth, in accordance with high-resource species. According to Chapin III et al. (1993), compared with slow-growing species, fast-growing species have a higher dependence on new environmental resources, which make them more vulnerable to fluctuations in resource availability. Other studies have demonstrated that species of high-resource environments take advantage of the water supply increase, while species adapted to stress are less plastic (Vilela et al. 2003; Otieno et al. 2005; Villagra \& Cavagnaro 2006).

Severe stress caused greater reductions in height, number of leaves, and $R G R$ of $L$. ferrea, suggesting that this species is more vulnerable to water stress than $P$. bracteosa. In a study conducted in the arid zone of Argentina, water stress also caused greater reductions in growth in a species typically found in an environment with high water resources (Prosopis alpataco) in comparison with one from a low water resource environment (Prosopis argentina). In general, the studied traits were reduced by $80 \%$ in the high-resource species and $60 \%$ in the low-resource species (Villagra \& Cavagnaro 2006). In another study in the savannas of Kenya, stress decreased the TDM and $L A$ by 45 and $26 \%$ respectively in a mesic habitat species (Acacia xanthophloea), and by only 40 and $15 \%$ in a species that resides in xeric habitats (Acacia tortilis) (Otieno et al. 2005). 
The abscission of leaflets by $L$. ferrea after 55 days in the $\mathrm{T}_{10}$ treatment also suggests a greater sensitivity to stress, since the early leaf fall in water deficit conditions indicates serious dehydration effects (Sala \& Tenhunen 1994; Fotelli et al. 2000; Villagra \& Cavagnaro 2006). The greater capacity of $P$. bracteosa seedlings to delay leaf abscission in $\mathrm{T}_{10}$ can be an advantage in relation to $L$. ferrea because after hydration $P$. bracteosa seedlings would not need to allocate assimilates to recover leaf area and may invest these resources in storage or defense functions.

The lowest $L A$ and SLA of P. bracteosa seedlings reflect greater adaptation to xeric conditions than $L$. ferrea seedlings. Taiz and Zeiger (2013) report that the reduction in leaf area is an adaptive mechanism that prevents water loss and maintains hydration, since less leaf area leads to less evapotranspiration, allowing the use of limited water supply in the soil for a longer period. According Cornelissen et al. (2003) species from environments with low resource availability tend to have lower $S L A$ than those from resource rich environments. Lower values of $S L A$ tend to correspond with relatively high investments in defense of the leaf (particularly structural) and high leaf longevity (Cornelissen et al. 2003). There is a close association between the potential growth rate of a species and its SLA; therefore, SLA can be considered the prime factor determining interspecific variation in RGR (Lambers \& Poorter 1992).

The $P$. bracteosa seedlings were less responsive to changes in water availability, showing minor adjustments in biomass allocation than $L$. ferrea seedlings. This is corroborated by the "proportional growth" results, in which $P$. bracteosa was higher than $L$. ferrea in $\mathrm{T}_{10}$ and less in $\mathrm{T}_{40}$ and $\mathrm{T}_{70^{\circ}}$. Stress tolerant plants have a set of morpho-physiological traits that allow them to survive in conditions of stress, but reduce the potential for growth in the absence of it (Chapin III et al. 1993; Grime 1977). Thus, these species with adaptive mechanisms to stress conditions generally show less phenotypic plasticity than species not adapted. P. bracteosa must then have mechanisms that allow it to survive under stressful conditions, but prevent it from taking advantage in increased water availability conditions.

Studies show that plants subjected to severe water deficit invest more in root elongation than in the shoot, which increases the potential to absorb water from the deeper layers of the soil profile (Barros \& Barbosa 1995; Barbosa et al. 2000; Silva \& Nogueira 2003; Figueirôa et al. 2004; Villagra \& Cavagnaro 2006). Contrary to what we expected, P. bracteosa seedlings did not present higher R/S ratio than $L$. ferrea seedlings under water stress conditions. However, the greater variation of $L$. ferrea (3-fold more than $P$. bracteosa) is in accordance with the generalization of Chapin III et al. (1993) that species in favorable habitats show greater plasticity in allocation patterns than species in stressful environments.

As water stress increases, plants promotes partial stomatal closure to prevent water loss by transpiration. This process alters gas exchange, limiting the availability of $\mathrm{CO}_{2}$ within the mesophyll, thus reduces the rate of photosynthesis (Filella et al. 1998; Gindaba et al. 2004; Scalon et al. 2011; Taiz \& Zeiger 2013). Contrary to what we expected, P. bracteosa seedlings had higher overall average photosynthetic rates than L. ferrea seedlings. This result is in accordance with other studies that demonstrated that stress-tolerant species maintained high $\mathrm{CO}_{2}$ uptake while grown under non-limiting water availability (DeLucia \& Heckathorn 1989; Patterson et al. 1997; Vilela et al. 2003), ruling out the likelihood that a trade-off between drought tolerance and $\mathrm{CO}_{2}$ uptake constrains tolerant species from occupying high-resource environments. Studies indicated that the main trait associated with inherently slow-growing species from low-resource environments is low SLA (Lambers \& Poorter 1992; Maranon \& Grubb 1993; Lambers et al. 1998).

In general, $P$. bracteosa demonstrated attributes of a lowresource species, showing a slow growth strategy and minor adjustments in biomass allocation, and tending to have higher water use efficiency than L. ferrea. The attributes of the SRS can determine the success of the establishment, growth, and survival of $P$. bracteosa seedlings under water stress, favoring its high population density in the caatinga. On the other hand, the characteristics of high-resource species, such as rapid growth and high resource acquisition, make $L$. ferrea more dependent on water resources and, consequently, suffer more negative impacts when these resources become scarce. Thus, these factors may explain the low population density of L. ferrea in areas of caatinga, suggesting that its occurrence in this environment might be relegated to microsites with higher and more constant water availability.

\section{Acknowledgments}

We thank the Taxonomists of Herbarium Prisco Bezerra for botanical identification of species; to Raimundo Nonato Costa Ferreira for help in the planning, installation and data collection for the experiment; and to CAPES - Coordenação de Aperfeiçoamento de Pessoal de Nível Superior for providing the scholarship.

\section{References}

Aerts R, Peijl MJ. 1993. A simple model to explain the dominance of lowproductive perennials in nutrient-poor habitats. Oikos 66: 144-147.

Aerts R, Chapin III FS. 2000. The mineral nutrition of wild plants revisited: a re-evaluation of processes and patterns. Advances in Ecological Research 30: 1-67.

Ahmad P, Jaleel CA, Sharma S. 2010. Antioxidative defense system, lipid peroxidation, proline-metabolizing enzymes and biochemical activity in two genotypes of Morus alba $\mathrm{L}$ subjected to $\mathrm{NaCl}$ stress. Russian Journal of Plant Physiology 57: 509-517.

Banzatto DA, Kronka SN. 2006. Experimentação agrícola. Jaboticabal, FUNEP.

Barbosa DC, Nogueira RJMC, Melo Filho PA. 2000. Comparative studies of growth in three species of "caatinga" submitted to water stress. Phyton 69: 45-50. 
Barros LM, Barbosa DCA. 1995. Crescimento de Acacia farnesiana (L.) Willd em casa de vegetação. Phyton 57: 179-191.

Cabral EL, Barbosa DCA, Simabukuro EA. 2004. Crescimento de plantas jovens de Tabebuia aurea (Manso) Benth. \& Hook. F. ex S. Moore submetidas a estresse hídrico. Acta Botanica Brasilica 18: 241-251.

Chapin III FS. 1980. The mineral nutrition of wild plants. Annual Review of Ecology and Systematics 11: 233-260.

Chapin III FS, Autumn K, Pugnaire F. 1993. Evolution of suites of traits in response to environmental stress. The American Naturalist 142: 79-92.

Coley PD, Bryant JP, Chapin FS. 1985. Resource availability and plant antiherbivore defense. Science 230: 895-899.

Cornelissen JHC, Lavorel S, Garnier E, et al. 2003. A handbook of protocols for standardised and easy measurement of plant functional traits worldwide. Australian Journal of Botany 51: 335-380.

Costa RC, Araújo FS. 2012. Physiognomy and structure of a caatinga with Cordia oncocalyx (Boraginaceae), a new type of community in Andrade-Lima's classification of caatingas. Rodriguésia 63: 269-276.

DeLucia EH, Heckathorn SA. 1989. The effect of soil drought on water-use efficiency in a contrasting Great Basin and Sierran montane species. Plant Cell Environ 12: 935-940.

Figueirôa JM, Barbosa DCA, Simabukuro EA. 2004. Crescimento de plantas jovens de Myracrodruon urundeuva Allemão (Anacardiaceae) sob diferentes regimes hídricos. Acta Botanica Brasilica 18: 573-580.

Filella I, Llusià J, Piñol J, Peñuelas J. 1998. Leaf gas exchange and fluorescence of Phillyrea latifolia, Pistacia lentiscus and Quercus ilex saplings in severe drought and high temperature conditions. Environmental and Experimental Botany 39: 213-220.

Fotelli MN, Radoglou KM, Constantinidou HI. 2000. Water stress responses of seedlings of four Mediterranean oak species. Tree Physiology 20: 1065-1075.

Gindaba J, Rozanov A, Negash L. 2004. Response of seedlings of two Eucalyptus and three deciduous tree species from Ethiopia to severe water stress. Forest Ecology and Management 201: 119-129.

Grime JP. 1977. Evidence for the existence of three primary strategies in plants and its relevance to ecological and evolutionary theory. The American Naturalist 111: 1169-1194.

Harper JL. 1977. Population biology of plants. London, Academic Press.

Keles Y, Oncel I. 2002. Response of antioxidative defense system to temperature and water stress combinations in wheat seedlings. Plant Science 163: 783-790.

Kranner I, Minibayeva FV, Beckett RP, Seal CE. 2010. What is stress? Concepts, definitions and applications in seed science. New Phytologist 188: 655-673.

Kitajima K, Fenner M. 2000. Ecology of seedling regeneration. In: Fenner M. (ed.) Seeds: The Ecology of Regeneration in Plant Communities, 2nd. edn. CAB International, Wallingford, p. 331-360.

Lambers H, Chapin FS, Pons TL. 1998. Plant Physiological Ecology. New York, Springer.

Lambers H, Poorter H. 1992. Inherent variation in growth-rate between higher plants - a search for physiological causes and consequences. Advances in Ecological Research 23: 187-261.

Larcher W. 2006. Ecofisiologia vegetal. São Carlos, Rima.

Lenhard NR, Scalon SPQ, Novelino JO. 2010. Crescimento inicial de mudas de pau-ferro (Caesalpinia ferrea MART. ex Tul. var. leiostachya Benth.) sob diferentes regimes hídricos. Ciência e Agrotecnologia 34: 870-877.

Lima BG. 2011. Composição florística e análise fitossociológica em duas áreas de caatinga no centro-sul cearense. $\mathrm{PhD}$ Thesis, Universidade Federal Rural do Semiárido, Brazil.

Maia GN. 2004. Caatinga: árvores, arbustos e suas utilidades. São Paulo, G\&Z Computação Gráfica e Editora.

Maranon T, Grubb PJ. 1993. Physiological basis and ecological significance of the seed size and relative growth rate relationship in Mediterranean annuals. Functional Ecology 7: 591-599.

McLaren KP, McDonald MA. 2003. The effects of moisture and shade on seed germination and seedling survival in tropical dry forest in Jamaica. Forest Ecology and Management 183: 61-75.

Mendes MRA. 2003. Florística e fitossociologia de um fragmento de caatinga arbórea, São José do Piauí, Piauí. Msc. Thesis, Universidade Federal de Pernambuco, Brazil.
Moles AT, Westoby M. 2004. What do seedlings die from and what are the implications for evolution of seed size? Oikos 106: 193-199.

Moreira ARP, Maracajá PP, Guerra AMNM, Sizenando Filho FA, Pereira TFC. 2007. Composição florística e análise fitossociológica arbustivoarbóreo no município de Caraúbas-RN. Revista Verde 2: 113-126.

Munns R. 2002. Comparative physiology of salt and water stress. Plant, Cell \& Environment 25: 239-250.

Mustroph A, Albrecht G. 2003. Tolerance of crop plants to oxygen deficiency stress: fermentative activity and photosynthetic capacity of entire seedlings under hypoxia and anoxia. Physiologia Plantarum 117: 508-520.

Otieno DO, Schmidt MWT, Adiku S, Tenhunen J. 2005. Physiological and morphological responses to water stress in two Acacia species from contrasting habitats. Tree Physiology 25: 361-371.

Patterson TB, Guy RD, Dang QL. 1997. Whole-plant nitrogen- and waterrelations traits, and their associated tradeoffs, in adjacent muskeg and upland boreal spruce species. Oecologia 110: 160-168.

Pearson TRH, Burslem D, Goeriz RE, Dalling JW. 2003. Regeneration niche partitioning in neotropical pioneers: effects of gap size, seasonal drought and herbivory on growth and survival. Oecologia 137: 456-465.

Pimentel C. 2004. A relação da planta com a água. Seropédica, Edur.

Queiroz LP. 2009. Leguminosas da caatinga. Feira de Santana, Universidade Estadual de Feira de Santana.

Roychoudhury A, Basu S, Sengupta DN. 2012. Antioxidants and stress-related metabolites in the seedlings of two indica rice varieties exposed to cadmium chloride toxicity. Acta Physiologiae Plantarum 34: 835-847.

Sala S, Tenhunen JD. 1994. Site-specific water relations and stomatal response of Quercus ilex in a Mediterranean watershed. Tree Physiology 14: 601-617.

Sampaio EVSB. 1995. Overview of the Brazilian caatinga. In: Bullock SH, Mooney HA, Medina E. (eds.) Seasonally dry tropical forests. New York, Cambridge University Press. p. 35-63.

Sampaio EVSB. 2010. Características e potencialidades. In: Gariglio MA, Sampaio EVSB, Cestaro LA, Kageyama PY. (eds). Uso sustentável e conservação dos recursos florestais da caatinga. Brasília, Serviço Florestal Brasileiro. p. 29-48.

Sausen TL, Rosa LMG. 2010. Growth and carbon assimilation limitations in Ricinus communis (Euphorbiaceae) under soil water stress conditions. Acta Botanica Brasilica 24: 648-654.

Scalon SPQ, Mussury RM, Euzébio VLM, Kodama FM, Kissmann C. 2011. Estresse hídrico no metabolismo e crescimento inicial de mudas de mutambo (Guazuma ulmifolia Lam.). Ciência Florestal 21: 655-662.

Silva EC, Nogueira RJMC. 2003. Crescimento de quatro espécies lenhosas cultivadas sob estresse hídrico em casa de vegetação. Revista Ceres 50: 203-217.

Silva EC, Nogueira RJMC, Azevedo Neto AD, Santos VF. 2003. Comportamento estomático e potencial da água da folha em três espécies lenhosas cultivadas sob estresse hídrico. Acta Botanica Brasilica 17:231-246.

Souza CC, Oliveira FA, Silva IF, Amorim Neto MS. 2000. Avaliação de métodos de determinação de água disponível e manejo da irrigação em terra roxa sob cultivo de algodoeiro herbáceo. Revista Brasileira de Engenharia Agrícola e Ambiental 4: 338-342.

Taiz L, Zeiger E. 2013. Fisiologia vegetal. Porto Alegre, ArtMed.

Valladares F, Martinez-Ferri E, Balaguer L, Perez-Corona E, Manrique E. 2000. Low leaf level response to light and nutrients in Mediterranean evergreen oaks: a conservative resource-use strategy? New Phytologist 148: 79-91.

Vieira DLM, Scariot A. 2006. Principles of natural regeneration of tropical dry forest for restoration. Restoration Ecology 14: 11-20.

Vilela AE, Rennella MJ, Ravetta DA. 2003. Responses of tree-type and shrub type Prosopis (Mimosaceae) taxa to water and nitrogen availabilities. Journal of Arid Environments 186: 327-337.

Villagra PE, Cavagnaro JB. 2006. Water stress effects on the seedling growth of Prosopis argentina and Prosopis alpataco. Journal of Arid Environments 64: 390-400.

Yin CY, Wu X, Duan BL, Luo JX, Li CY. 2005. Early growth, dry matter allocation and water use efficiency of two sympatric Populus species as affected by water stress. Environmental and Experimental Botany 53: $315-322$ 